Among Neotropical monkeys, members of the subfamily Pitheci inae, with three genera and eight species, are among the least known with respect to their ecology and behaviour (Hershkovitz, 1972, 1979; Napier, 1976).

All pithecine species are similar in being medium-sized $(1.5-3.6 \mathrm{~kg})$, diurnal, arboreal, and frugivorous; however, there are some major differences among their social structures. For example, the bearded sakis, Chiropotes, and uakaris, Cacajao, live in muitimale troops (Fontaine, 1981; van Roosmalen et al., 1981; Ayres, 1981), whereas the sak is are reported to live in smal ler monogamous groups ranging from 2 to 6 individuals (Izawa, 1975; Muckenhirn et al., 1975; Buchanan et al., 1981; Happel, 1982).

Several accounts in recent literature (e.g. Muckenhirn et al., 1975;Moynihan,1976 Neville, 1976; Hernandez-Camacho \& Cooper, 1976; M1ttermeier \& Coimbra-Filho, 1977; Ayres \& Milton, 1981; Ayres, 1981; Freese et al., 1982) provide basic information on the genus Pithecia, especially regarding population density and general aspects of the ecology in their natural habitats. Others (e.g. Fooden, 1964; Izawa, 1975; Izawa \& Yone da, 1981) provide information on diets of P. pithecia, P. monachus andP.hirsuta through analysis of stomach contents of wild shot specimens. More recently, Buchanan et al., (1981), Mittermeier \& van Roosmalen (1981), Fleagle \& Mittermeier (1980) and Happel (1982) collected more detailed information on the general aspects of the ecology and behaviour of $\mathbf{P}$. pithecia in Surinam and $\mathbf{P}$. hirsuta in Peru.

The geographical range of the Guianan Saki (Pithecia pithecia) is confined to the north bank of the Amazon River west of the Rio Negro as well as the coastal forests of northern Brazil (Amapa Territory) and the Guianan countries (Hershkovitz, 1979), an area of approximately $1.350 .000 \mathrm{~km}^{2}$. P. pithecia is the most sexually dichromatic

(*) Dept. of Ecology - Instituto Nacional de Pesquisas da Antazönia, Cx. Postal 478, Ma naus, 69.000 AM - Brazi1.

(**) Dept. of Anatomical Sciences, State University of New York, Stony Bronk 11794 , New York, U.S.A. 
species in the genus. Males are uniformly black with the contrasting facial mask and the front part of the neck ranging from pale white or yellow to dark brown (perhaps varying geographically). The females are predominantly dark brown dorsally and paler ventrally. The females of this species are quite similar to both sexes in P. monachus. Six adult males collected by INPA and FSESP biomedical programs had mean body weights of $1.97 \mathrm{~kg}$ and body lengths of $358 \mathrm{~mm}$. The fenales $(n=3)$ weighed $1.59 \mathrm{~kg}$ and were 330 $m m$ in length (Table 1 ).

\section{Study Site and Methods}

This research was carried out in a forest reserve belonging to the Tropical Hotel, located on the left bank of Negro River near the Tarumã-açu Tributary. The area is roughly $30 \mathrm{~km}$ west of Manaus, comprises a 1 ittle over 20 hectares and is completely surrounded by a $2 \mathrm{~m}$ high fence which protects it against intruders and hunting. The area is bounded by the Rio Negro to the south, the grounds of the Tropical Hotel to the east and secondary forest to the north and west, separated by marginal dirt roads.

The climatic data for the Ducke Forest Reserve (INPA/CNPq), $24 \mathrm{~km}$ nor theast of the city of Manaus (Ribeiro EVilla Nova, 1979), probably applies as well to the study site. The average annual rainfall is $2,478 \mathrm{~mm}$. According to Thornthwaite's (1948) water balance method, this region is characterized by two distinct seasons. The wet season, from December to June, has an average of $970 \mathrm{~mm}$ of water excess; and the dry season, from August to the middle of November has an average of $28 \mathrm{~mm}$ water deficit in the soil.

Five physiognomic vegetation types are distinguished in this area (Figure 1). A) Logged forest, about 35\%, characterized by absence of emergent trees which had probably been removed by selective logging. Remaining trees range from 20 to $30 \mathrm{~m}$ height. B) Cam pinarana $(6 \%)$ characterized by white sand soil, with cover lower than that of the former. c) old secondary forest ( $45 \%$ ): the original forest had been partially removed and the area is characterized by small trees, shrubs and 1 ianas. This vegetation has a low biomass and never exceeds $15 \mathrm{~m}$ in height. D) The remaining $2 \%$ consists of patches characterized by the abundance of palms.

The monkey population of the study site in 1981, consisted of eight P. pithecia and one or two groups of Saguinus bicolor bicolor.

In October 1980, approximately $9 \mathrm{~km}$ of trails were established, dividing the whole area into $50 \mathrm{~m} \times 50 \mathrm{~m}$ quadrats to provide better access to the monkeys and facilitate data quantification. The results described here were gathered during 45 days of research throughout 1981, but the bulk of it was obtained at the end of January and the beginning of August ( 18 days). In these periods, it was possible to contact the monkeys on 128 occasions, and each time they were located, we followed them for as long as possible. These sightings lasted from a few minutes to almost four hours. The monkeys were never habituated to the observers, but if the group was lost, it was possible to relocate them the same day. 


\section{Population Density and Structure}

In 1981, the population of sakis in the study area consisted of two adult males, three adult females, one male and one female subadult (or young adult), and an infant female. Various combinations of individuals were sighted on 80 occasions during the course of the study (Table 2), and the population appeared to consist of three socia) groups of variable stability (Table 3 ). The most stable group was "A", consisting of an adult male, an adult female, and an infant female, born late 1980. Members of this family were invariably found together. Group "B" consisted of one adult male and two females (one adult and the other subadult or young adult). Although these animals were sighted less frequently than those in Group "A", they seemed to be a new group which had formed during the time of the study, probably of individuals from the other two groups.

The female " $C$ " was probably from Group " $B$ " since she was usually found with those individuals during the first period of observations. However, between the January observations and those in July, her time with male " $\mathrm{C}$ " increased from $8 \%$ to $24 \%$. The male " $C$ " probably originated in Group " $A$ " since in the first period it was seen in $12 \%$ of the observations with this group while in the next period it was only seen in $5 \%$. Another possibility for these changes within the population is the seasonality and availability of food in that area, but there are no data on the phenology of the trees. In any case associations between individuals were not uncommion and they have an apparently flexible social structure. Associations of 7 individuals $(A+B+a$ female) were more comon in the first half of the year.

The mean group size in the study area was 2.7 individuals. Another group of the species, observed in lowland primary forest at the Dimona Farm, $80 \mathrm{~km}$ north of Manaus, had three individuals. Other reports on group size for this species are given byMuckenhirn et al. (1975), Buchanan et al. (1981). These authors saw a total of 19 groups of this species in the Guianas and their mean size was 2.9 with a range from 1 to 5 individuals. It is likely that these authors may have seen occasional associations between groups, but the basic social unit, was the family composed of one adult male, one adult fenale and their offspring.

Freese et al. (1982) report 20 sightings of P. monachus with a mean group size of 2.8 and a range from 1 to 8 individuals. Happel (1982) reports 4 groups of $\mathbf{p}$. hirsuta in Peru, with a mean group size of 4.5 , ranging from 4 to 5 individuals.

Population density for the area was 40 individuals $\mathrm{km}^{2}$ or $55-60 \mathrm{~kg} / \mathrm{km}^{2}$. This is a higher density than found at any of the six study sites surveyed by Freese et al. (1982) in Bollvia and Peru for P. monachus. It is also higher than those reported by Buchanan et al. (1981) and Muckenhirn et al. (1975) for P. pithecia in Surinam and Guiana. This is probably due to isolation of the study site and absence of other competing primates as well as the ability to conduct an accurate census of all individuals.

\section{Diet}

On 29 occasions, individuals of P. pithecia were observed feeding on vegetable 
material. In $62 \%$ of the observations they were feeding on ripe mesocarps, $17 \%$ on immature seeds, $14 \%$ on flowers and on one occasion they were feeding on young leaves af Trymatococus amazonicum (Moraceae), and the shoots of another plant of the same family, Cecropia scyadophylla. Most of the mature mesocarps belonged to the palm trees, Mauritia flexuosa and Denocarpus bacaba. In January and February, when fruits of the former are available, they fed mostly on this species, of which there were 8 trees in the whole area. In July and August, they seem to have a more varied diet, including both seeds and leaves. Flowers were only eaten in February from three different families:Bignoniaceae, Leguminosae and Passifloraceae (Table 4).

Because the animals never became habituated to the observers, there is a large chance of bias in our sample. First, it is based on spot observations, not time spent feeding. Secondly, fruits are more easily recorded in the sample because we could observe what had been eaten when the parts dropped to the ground. It is unclear whether they feed on animalmatter. On one occasion after a monkey had left a tree, we found some empty pupae which had been opened a few minutes earlier. Fooden (1964) and Mittermeier (Buchananet al., 1981) found only fruits in the stomach contents of P. pithecia, although lzawa (1975) and Izawa and Yoneda (1981) found leaves mixed with insects for two other species of this genus. Buchanan et al. (1981) document 22 feeding observation for P. pithecia in Surinam and found $54.5 \%$ feeding observations of seeds and $36 \%$ mesocarps. These authors also report flower eating for the species. Happel (1982) reports $16 \%$ of feeding bouts on leaves, $53 \%$ of ripe mesocarps and 18\% of seeds (legunes and other fruits) for P. hirsuta in Peru.

\section{Ranging Behaviour, Habitat use and Periods of Activity}

The eight individuals of P. pithecia used an area of 13.5 hectares, or $67 \%$ of the total area available (Figure 2). The home range of Group "A" was between 8 and 9 hectares (Figure 3) and there was a considerable anount of overlap between this group and the other individuals of $\mathbf{P}$. pithecia. The core area of group "A" was only 2.5 hectares.

1t was never possibie to follow the monkeys from sunrise to sunset. Our longest record of continuous contact was almost four hours during which the group travelled 635 m. Most of the time, however, the monkeys were fleeing from the observer. Sometimes the animals were spotted several times during the same day and on suchoccasions, we could estimate a day range length, which was found to be between 0.3 to $0.5 \mathrm{~km}$.

To estimate the habitat preferences for the individuals in the area, we have used an index of habitat selectivity ("S") which was calculated as follows.

$$
\text { Relative frequency of monkey sightings in that forest type }
$$

$S=$

How much of that forest type was available (\%)

Thus, higher values for "S" indicate areas that have been selected (Table 5.) The 
results show that the sakis used the logged forest 1.5 times more often than they used the secondary forest. However, if we examine the selectivity, use of logged forest is 2.5 times greater because there was less logged forest available than secondary. The preference for the other two vegetation types does not differ much from that found for the secondary forest.

Buchanan et al. (1981) report a variety of different habitats for the genus includ ing high forest, mountain savannah forest, liana forest, ridge and secondary forest. In the Voltzberg Nature Reserve in Surinam, $42.2 \%$ of the total observations $(N=31)$ were in high forest, but they do not mention how much of each type of forest was available. Our data confirms that $\mathbf{P}$. pithecia can live in a wide variety of habitats. Despite this potential to live in a wide range of vegetation types, they have a higher selectivity for less disturbed forest types.

Most activity occurs in the morning and early in the afternoon between 0555 to 1300 hs. In only $10 \%$ of the occasions were the animals seen active after 1300 hs.lt is not clear, however, why they stop their activities so early, al though it may be related to the limitation of resources due to the isolation of the area.

\section{Interactions with the Pied Tamarin (Saguinus bicolor bicolor)}

On several occasions Group "A" was seen passing near one of the groups of $S$. $b$. bicolor, although the two species were never seen in the same tree during our observa tions. There is a high degree of overlap between home ranges of these species, but the space used by S. B. bicolor is greater than that of P. pithecia. Also, the sakispreferred the central portion of the reserve while the pied tamarins could be seen in the new secondary patches. P. pithecia never made use of that vegetation.

Buchanan et al. (1981), Mittermeier and van Roosmalen (1981) and Happel (1982)report associations between Saguinus sp. and Pithecia and with other primate genera. On some occasions, these two genera were seen feeding on the same tree. It is possible that since both genera can make use of secondary growth forest and other similar habitat there is a higher probability of finding them together, but it is not as common a relationship as reported, for example, by Fleagle et al. (1981) for Cebus apella and Saimiri sciureus.

\section{Reproduction and Parental Care}

It is possible that the infant from group " $A$ " was born in the end of November or December 1980. On November 20th we did not see an infant among the individuals of P. pithecia. When we renewed observations in January of the following year, however, we saw the female infant. No copulations were seen in this population. An infant is normally carried by the female until at least the end of the second or third month when it becomes partially independent of the mother; even though it is still unable totravel alone 
for even short distances. Most of our observations were on group "A" because it was the easiest to follow. Since the adult could not flee without the infant, carrying it required them to move more slowly than the other group in the canopy. Because it was not as agile, it rarely came to the lower strata, but remained in the canopy where there are more branches and where locomotion is, therefore, easier for the infant.

On the first series of contacts, the distances from the observer were never less than 30-40 m. On these occasions, the adult male wouid remain in an intermediate positian where it could see the observer, while the female and infant moved away some 50 meters. They would signal the male with a whistle and he would rejoin the group.

On other occasions the female and infant remained immobile, hidden in the canopy of the tree while the male moved up to $100 \mathrm{~m}$ away to attract our attention. Then the female would move away with the young.

On three occasions, the male was with the infant while the female was nearby, but he was never seen carrying the infant.

\section{Locomotion}

White and brown-face sakis (P. pithecia) are amongst the most spectacular leapers of all Neotropical primates (Fleagle \& Mittermeier, 1980), as indicated by their common name of "monos voladores" (flying monkeys). During the course of our observations, we made notes on locomotor behavior of the monkeys and in late July and August made quant $i$ tative assesments of their use of different locomotor patterns.

Leaping is the most common locomotor pattern used by sakis and accounts for nearly 75\% of their locomotor activity (Figure 4) when they are travelling about their home range, either in moving between food trees or fleeing potential predators. The leaping ability of the sakis enables them to exploit a wide range of forest types, where the ar boreal supports may be horizontally discontinuous. In travelling, the sakis leap between all combinations of horizontal branches and vertical trunks.

Quadrupedal walking and running are much less common than leaping when the sakis are travelling. In general, they seem to be rather awkward quadrupeds, probably because of their relatively long legs.

Sakis rarely use any type of suspensory behavior. They occasionally climb up lianas, vines and various small tree trunks. Between leaps, the monkeys frequently use a series of rapid hand holds to change direction or to pull up on top of a branch, an activity that is probably responsible for the reports of "brachiation" in this genus. We never saw any extended bouts of purely bimanual progression.

We have less quantitative data on locomotion during feeding and on habitual postures. Like most primates (e.g. Fleagle \& Mittermeier, 1980; Fleagle, 1980), sakis seem to rely less on leaping and more on quadrupedal walking when they are feeding rather than travelling. Sakis use both seated postures and frequently vertical clinging postures when feeding and resting. The latter are particularly common on lianas and 
vertical tree trunks (Figure 5).

These observations in Brazil are virtually identical with those of the samespecies in Surinam (Fleagle and Mittermeier, 1980; Buchanan et al., 1981) which portray these animals as prolific leapers. Happel (1982), however, describes P. hirsuta in Peru as being more quadrupedal, al though leaping did account for almost one third of this author's observations. Earlier reports on Pithecia as slow sloth-like animals almost certainly are based on the animal's frequent habit of hiding from observers, viewed as potential predators, or quietly slipping away through tangled vegetation.

\section{Discussion}

In many aspects, our observations of Pithecia pithecia from Manaus agree with those of others who have studied this species elsewhere (Buchanan et al., 1980; Fleagle \& Mittermeier, 1980; Mittermeier \& van Roosmalen, 1981). The data suggest they are small, saltatory frugivores which live in a variety of forest types where they seem to frequent the understory and lower canopy levels. In gross diet, general dental features and digestive tract Pithecia resembles Chiropotes (Fooden, 1964; Hershkovitz, 1977). The two genera of Pithecinnae differ, however, in body size, social or ganization, habitat preferences, canopy use and locomotion. In contrast to Pithecia, Chiropotes lives in larger groups of up to 26 individuals (which can break down into smaller foraging units); is largely restricted to terra fime primary forests; prefers the middle and upper levels of the main canopy; and is almost exclusively quadrupedal (Ayres, 1981; van Roosmalen et al., 1981; van Roosmalen \& Mittermeier, 1981). How are these differences functionally interrelated in the different strategies used by these genera for exploiting the same Amazonian region?

The small individual size, small group size, leaping, understory use, and broad preferences of $\mathbf{P}$. pithecia are almost certainly interrelated. Arboreal primates which frequent the understory and Iower canopy levels are usually excelient leapers because this part of forest usually has few horizontal branches, but many vertical supports such as tree trunks and $l i a n a s$, which can best be visited by leaping across horizontal gaps (Fleagle, 1978; Fleagle \& Mittermeier, 1980; Fleagle, 1983). Leapers also seem to do better in secondary forest for similar reasons (Fleagle, 1980). At the same time, mo bility and visibility are likely to be somewhat restricted in this milieu. As small monkeys living in small groups, Pithecia pithecia can subsist on fewer resource units spread thinly throughout forest. Likewise, they can find sufficient suitable resources in a variety of habitats.

Bearded sakis, thiropotes, in contrast, travel quadrupedally in large groups searching for massed food supplies. They cover large home ranges (up to 300 hectares). They use the middle and upper canopy levels in primary forest, which enables them to move rapidly along fairly continuous horizontal networks of branches and also permits considerable intergroup visibility on those occasions when larger groups break up into smaller units.

Preliminary notes ...

INSTITUTO NACIONAL DE
PESQUISAS DA AMAZÔNIA INPA - CODC 
These differences are most apparent during the period when there is a shortage of potential foods (Alencar et al., 1979). In the first period of our study, equivalent to the beginning of the wet season, the sakis tended to feed on ripe mesocarps of fruit rich in protein and fat such as Mauritia flexuosa (Aguiar et al., 1980) and larger asso ciations were more common in this period. In Aripuanä (MT, Brazil) Chiropotes albinasus fed at the equivalent time of the year on fruits such as Astrocaryium vulgare, Caryocar villosum and Onychopetalum amazonicum (for which they have the highest selectivity) which are rich in fat and protein as well (Ayres, 1981). In other periods, seed preda tion increases for Chiropotes albinasus while P. pithecia has a more diversified diet, including young leaves, shoots and flowers.

As Happel (1982) reported, one of the most interesting features of Pithecia is that there is absence of territoriality in a monogamous primate. Territoriality among animals is related to the extent to which food sources and mates are defendable. In Pithecia, the question still remains because the population studied in this case could be a single group, since we found a great flexibility in their social structure. Usually members of genus Pithecia are not found continuously throughout the forest; they seem to have aclumpeddistribution in certain sections of the terra firme. A study of more than one of these clumps is obviously needed in order to clarify if Pithecia is or is not an exception among monogamous primates.

\section{ACKNOWLEDGEMENTS}

We wish to thank INPA/CNPq for the financial help for this project, and Dr. D. J. Chivers, Dr. P. Hershkovitz, J. 0. Caldecott, A. Johns, \& W. R. Konstant for criticisms on an earlier version of this manuscript. J. G. Fleagle was supported by research grants BNS 7724921 and BNS 24149 from the U. 5. National Science Foundation.

Table 1. Body weight and length of wild shot Pithecia pithecia in the Brazilian Amazon by the parasitological and virus research programmes of INPA and FSESP.

\begin{tabular}{|c|c|c|c|c|}
\hline Sex & Age & $\begin{array}{c}\text { Body Weight } \\
(\mathrm{kg})\end{array}$ & $\begin{array}{l}\text { Head \& Body } \\
\text { Lenght }(\mathrm{mm})\end{array}$ & locality \\
\hline$M$ & $?$ & ? & 230 & Manaus \\
\hline$M$ & $?$ & 1.47 & 334 & Manaus \\
\hline$M$ & Ad. & 1.76 & 351 & Manaus \\
\hline$M$ & $?$ & 1.38 & 306 & Manaus \\
\hline$M$ & Ad. & 1.65 & 330 & Trombetas \\
\hline$M$ & Ad. & 1.95 & 345 & Trombetas \\
\hline$M$ & Ad. & 2.50 & 390 & Trombetas \\
\hline 4 & Ad. & 2.15 & 390 & Trombetas \\
\hline$M$ & Subad. & 1.55 & $\$ 65$ & Trombetas \\
\hline$M$ & Juv. & 0.39 & 210 & Trombetas \\
\hline B & Ad. & 1.80 & 340 & Trombetas \\
\hline$F$ & $?$ & 1.25 & 292 & Manaus \\
\hline$F$ & Ad. & 1.77 & 352 & Manaus \\
\hline$F$ & Ad. & 1.75 & 330 & Trombetas \\
\hline$F$ & Ad. & 1.26 & 310 & Trombetas \\
\hline
\end{tabular}


Table 2. Group size and composition for the population of Pithecia pithecia living in a 20 ha forest, west of Manaus, on the left bank of rio Negro (1981).

\begin{tabular}{|c|c|c|c|c|c|c|c|}
\hline Un it & $\begin{array}{l}\text { Adult } \\
\text { male }\end{array}$ & $\begin{array}{l}\text { Adult } \\
\text { female }\end{array}$ & $\begin{array}{l}\text { Subadult } \\
\text { male }(*)\end{array}$ & $\begin{array}{l}\text { Subadult } \\
\text { female }(: t)\end{array}$ & $\begin{array}{l}\text { Infant } \\
\text { male }\end{array}$ & $\begin{array}{l}\text { Infant } \\
\text { female }\end{array}$ & Total \\
\hline$' A '$ & 1 & 1 & - & $=$ & - & r & 3 \\
\hline 'B' & 1 & 2 & - & - & - & - & 3 \\
\hline${ }^{2} C^{1}$ & - & - & 1 & d) & - & - & 2 \\
\hline
\end{tabular}

(*) = or young adult.

Table 3. Associations between groups and individuals of pithecla plthecla in the re serve on the left bank of the rioNegrowest of Manaus (only $1^{\text {s* }}$ sight observations were used in this sample).

\begin{tabular}{|c|c|c|c|c|}
\hline Association & $\begin{array}{l}\text { lan-Feb. no. } \\
\text { obs. }(n=25)\end{array}$ & $\begin{array}{c}\text { Frequency } \\
(*)\end{array}$ & $\begin{array}{l}\text { Jul-Aug. no. } \\
\text { obs. }(n=55)\end{array}$ & $\begin{array}{c}\text { Frequency } \\
\text { (*) }\end{array}$ \\
\hline 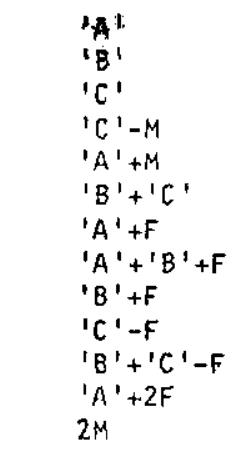 & $\begin{array}{l}10 \\
2 \\
2 \\
0 \\
3 \\
0 \\
0 \\
3 \\
2 \\
3 \\
0 \\
0 \\
0\end{array}$ & $\begin{array}{r}40 \\
8 \\
8 \\
0 \\
12 \\
0 \\
0 \\
12 \\
0 \\
12 \\
0 \\
0 \\
0\end{array}$ & $\begin{array}{r}12 \\
7 \\
7 \\
8 \\
3 \\
6 \\
5 \\
0 \\
3 \\
3 \\
1 \\
1 \\
1\end{array}$ & $\begin{array}{r}22 \\
13 \\
13 \\
15 \\
5 \\
11 \\
9 \\
0 \\
2 \\
5 \\
2 \\
2 \\
2\end{array}$ \\
\hline
\end{tabular}

$M=$ adult or subadult male; $F=$ adult or subadult female. 
Table 4. Foods and feeding frequency of Pithecia pithecia in the study site on the left bank of the rio Negro, west of Manaus, Amazonas, Brazi) in 1981 ( $n=29$ obs.).

\begin{tabular}{|c|c|c|c|c|c|c|}
\hline Specles & Family & Part eaten & Freq. & Habit & Height & Month (s) \\
\hline Mauritia flexuosa & Palmae & Mature mesocarp & 8 & tree & 25 & Feb. ,Mar. \\
\hline Oenocarpus bacaba & Palmae & Mature mesocarp & 5 & tree & 8 & Aug. \\
\hline Species no I (NI) & Bignoniaceae & Flower & 2 & liana & 12 & Feb. \\
\hline Species $n \div 2$ (NI) & Bignon i aceae & Young seeds & 1 & liana & 7 & Jun. \\
\hline Passiflora sp. & Passifloraceae & Flower & 1 & 1 iana & $\dot{6}$ & Feb. \\
\hline Inga sp. & Leguminosae & Mature mesocarp & 2 & tree & 12 & Jan., Jul. \\
\hline Clitoria amazonica & Legurninosae & Flower & 1 & li ana & 5 & Feb. \\
\hline Maximiliana sp. & Palmae & Mature mesocarp & 1 & tree & 4 & Feb. \\
\hline Couma utilis & Apocynaceae & Mature mesocarp & 1 & tree & 12 & Jul. \\
\hline Simphonia sp. & Gutt iferae & Young seeds & 3 & tree & 13 & Jul. \\
\hline Trymatococus amazon icum & Moraceae & Young leaves & I & tree & 6 & Jul. \\
\hline Qualea retusa & Vochysiaceae & Young seeds & $y$ & tree & 15 & $?$ \\
\hline Cecropia scyadophylla & Moraceae & Young shoots & 1 & tree & 6 & Jul. \\
\hline Bellucia sp. & Melastomataceae & Mature mesocarp & 1 & tree & $?$ & sul. \\
\hline
\end{tabular}


Table 5. Selectivity of Plthecia pithecia for four different vegetation types at the reserve, on the left bank of the rio Negro, west of Manaus, Brazil.

\begin{tabular}{|c|c|c|c|c|}
\hline Type of vegetation & $\begin{array}{l}\text { Absolute } \\
\text { frequency } \\
\text { (sightings) }\end{array}$ & $\begin{array}{l}\text { Relative } \\
\text { frequency } \\
\quad(\%)\end{array}$ & $\begin{array}{l}\text { Total } \\
\text { disponible } \\
\end{array}$ & $\begin{array}{c}\text { Selectivity } \\
\text { ('S') }\end{array}$ \\
\hline Logged forest & 117 & 0.58 & 0.35 & 1.66 \\
\hline $\begin{array}{l}\text { Secondary forest } \\
\text { (old and new) }\end{array}$ & .76 & 0.38 & 0.57 & 0.67 \\
\hline $\begin{array}{l}\text { Camp inarana } \\
\text { (white sand) }\end{array}$ & 7 & 0.03 & $\pi .06$ & 0.50 \\
\hline $\begin{array}{l}\text { Palhal } \\
\qquad \text { (PaIm patches) }\end{array}$ & 2 & 0.01 & 0.02 & 0.50 \\
\hline TOTAL & 202 & 1.00 & $1+90$ & $\rightarrow$ \\
\hline
\end{tabular}

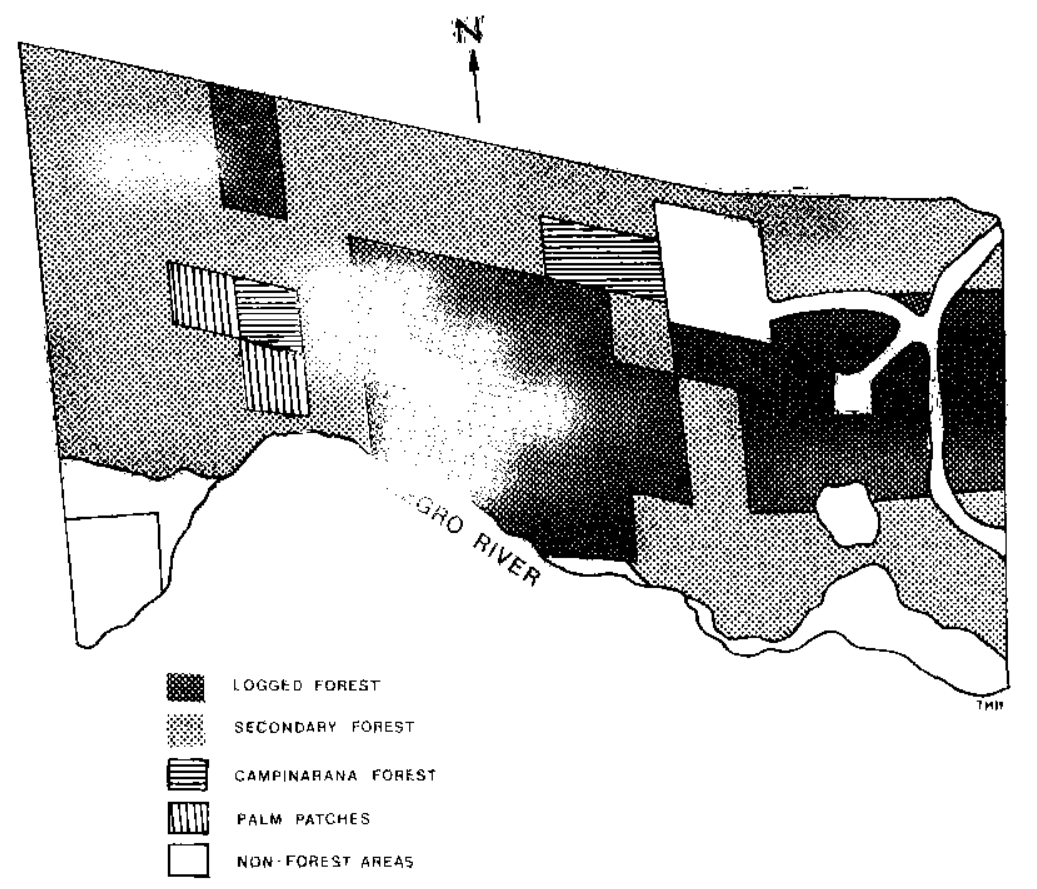

FIG. 1 - Study site and the distribution of five physiognomical vegetation types in the area. 


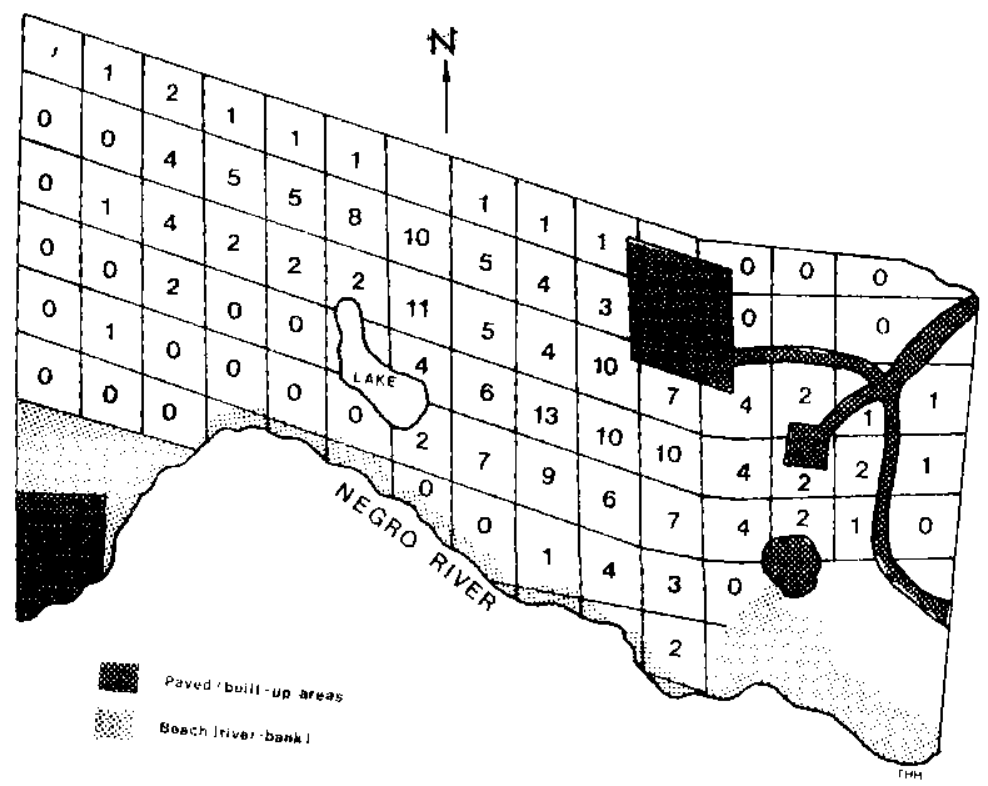
FIG. 2 - The space used by the Pithecia pithecia population at the Tropical Hotel
reserve, Manaus, AM, Brazil (the numbers correspond to the frequency of
sightings of this species in each quadrat of $50 \times 50$ meters)

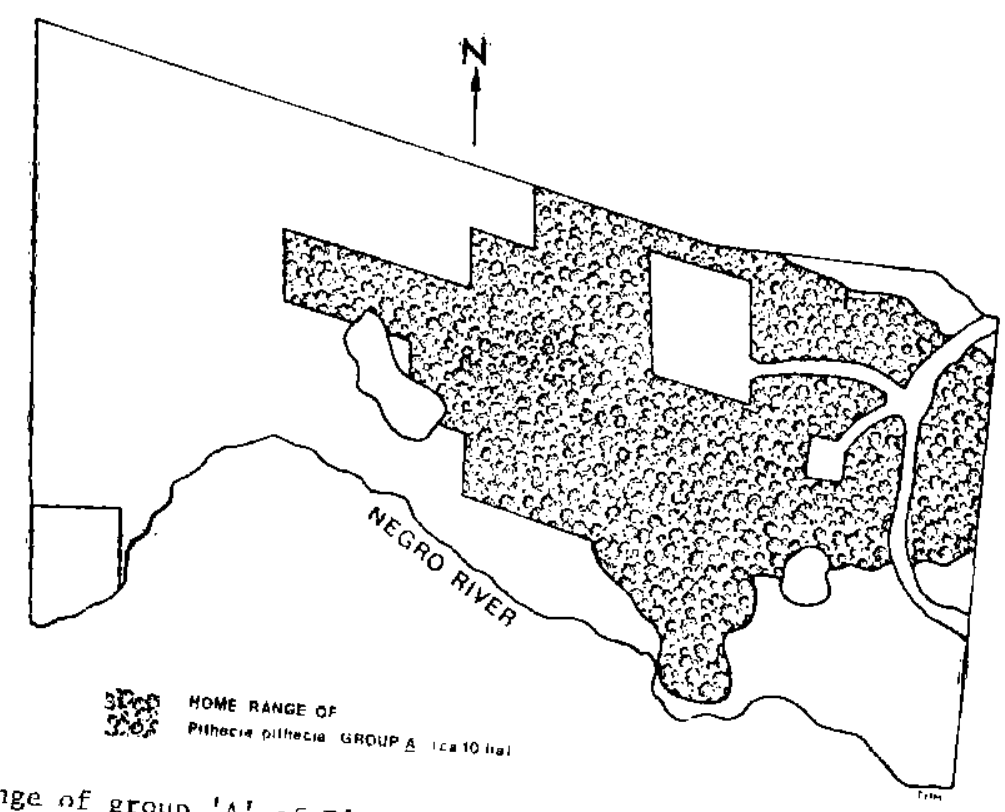

FIG. 3 - tome range of group 'A' of Pithecia pithecia during the study period in 1981. 


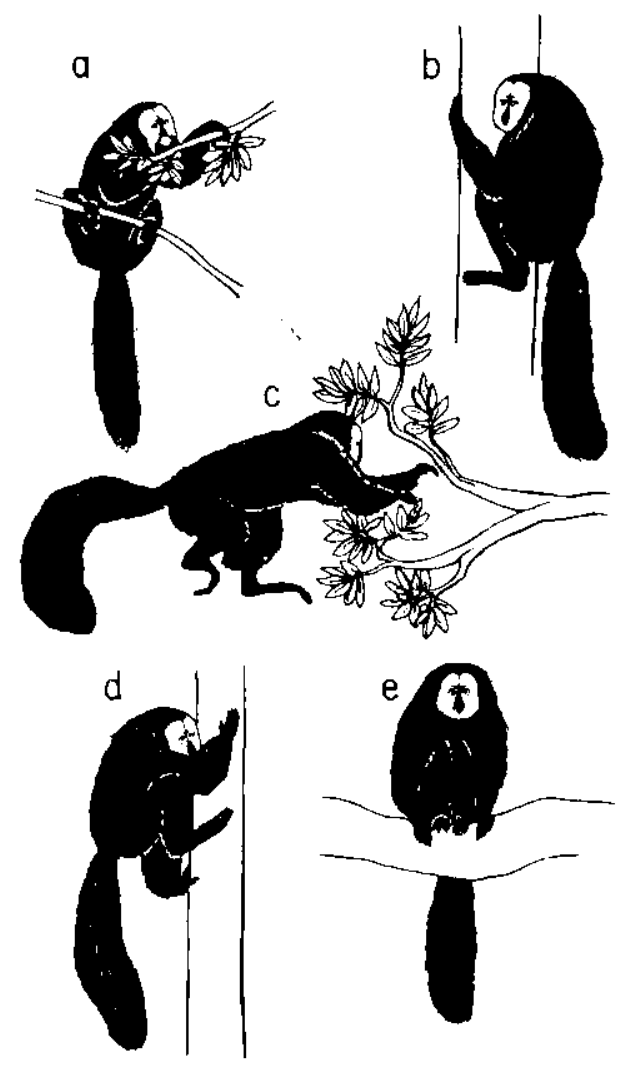

FIG. 4 - Typical locomotion and postural activities in Phitecia pithecia. a) Sitting and feeding on a branch. b) "Vertical clinging" on a trunk. c) Leaping into foliage. d) Climbing up a vertical trunk. e) Sitting on a bough.

\section{BOUTS OF LOCOMOTION DURING TRAVEL}

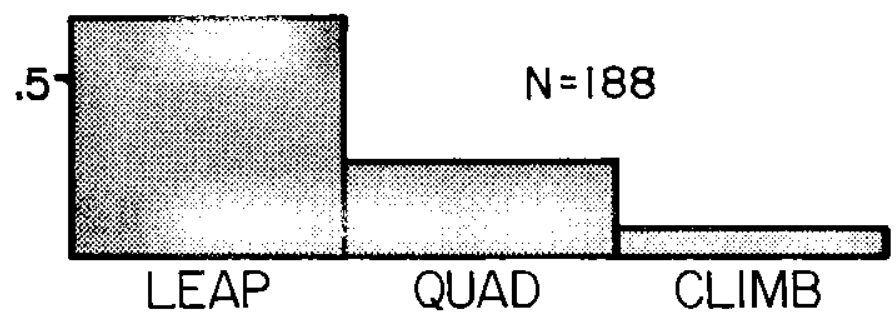

\section{DISTANCE TRAVELED}

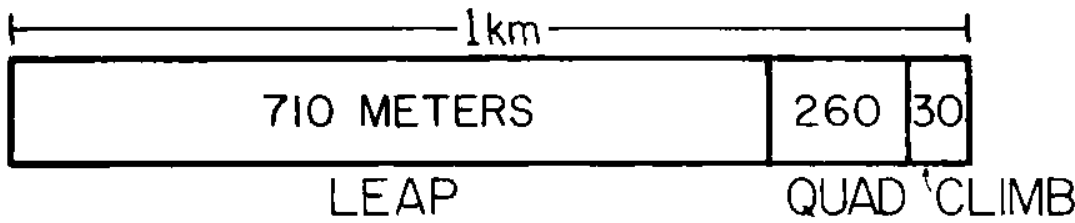

FIG, 5 - Quantitative analysis of the locomotor behavior of Pithecia pithecia showing percentage of locomotor bouts devoted to leaping, quadrupedal walking and running, and climb and the contribution of each of these locomotor activities to each kilometer of travei. 


\section{References}

Aguiar, J. P. L.; Marinho, H. A.; Rebelo, Y. S.; Shrimpton, R. - 1980. Aspectos Nutritivos de alguns frutos da Amazônia. Acta Amazonica, 10 (4): 755-758.

Alencar, J. C.; Almeida, R. A.; Fernandes, N. P. - 1979. Fenologia de espécies florestais em floresta tropical úmida de terra firme na Amazónia Central. Acta Amazonica, 9 (1): $163-198$.

Ayres, J. M. - 1981, Observaçóes sobre a ecologia e o comportamento dos cuxius (Chiropotes albinasas and Chiropotes satanas; Cebidae: Primates) Belém, Ed. FADESP Grafi sa. $142 \mathrm{p}$.

Ayres, J. M. \& Milton, K. - 1981. Levantamento de Primatas e Habitat no Rio Tapajö, Bolt. do Huseu Paraense Emílio Goeldi, N. S., Zoologia, (111): 1-11, dez.

Buchanan, D.; Mittermeier, R.A.; Roosmalen, M.G.M. van - 1981. The sakis, genus Pithecia. In: Coimbra-Filho, A.F. \& Mittermeier, R.A. ed. - Ecology and Behaviour of Neotropical Primates. Rio de Janeiro, Academia Brasileira de Ciências. p. $391-417$.

Fleagle, J.G. - 1978. Locomotion, posture and habitat use of two sympatric leaf monkeys in west Malaysia. In: Chivers, D.J. \& Herbert, J. ed. - Recent Advances in Primatology, v. 1. Behaviour, New York, Academic Press. p. 331-336.

- 1980. Locomotion and Postures. In: Chivers, D. J. ed. - Malayan Forest Primates: Ten Years'Study in Tropical Rain Forest. New York, Plenum Press. p. 191-207.

- 1983. Primate Locomotion and Jiet. In: Chivers D. J. ed.- Food Acquisition and Processing in Primates. N. Y. Plenum Fress. p. 105-117.

Fleagle, J. G. \& Mittermeier, R. A. - 1980. Locomotor behavior, body size and comparative ecology of seven Surinam monkeys. American Journal of Physical Anthropology, 52 $301-322$,

Eleagle, J. G.; Mittermeier, R. A.; Skopec, A. L. - 198l. Differential habitat use by Cebus apella and Saimiri sciureus in Central Surinam. Primates, 22: 361-367.

Fontaine, R. - 1981. The Uakaris, genus Cacajao. In: Coimbra-Filho, A. F. \& Mitterme ier, R. A. - Ecology and Behavior of Neotropical Primates. Rio de Janeiro, Academia Brasileira de Ciëncias, p. 443-493.

Fooden, J. - 1964. Stomach contents and gastro-intestinal proportions in wild shot Guianan monkeys. Anerican Journal of Physical Anthropology, 22: 227-232.

Freese, C. H.; Heltne, P. G.; Castro, R.; Whitesides, N. G. - 1982 . Patterns and Deter minants of Monkey Densities in peru and Bolivia, with notes on Distributions. Inter national Journal of Primatology, 3(l): 53-90.

Happe1, R. E. - 1982. Ecology of Pithecia hirsuta in Peru. Journal of Human Evolution 11: $581-590$.

Hernandez-Camacho, J. \& Cooper, R. W. - 1976. The nonhuman primates of Columbia. In: Thorington Jr., R. W. \& Heltne, P. G. eds. - Neotropical Primates: Field Studies and Conservation. Washington, National Academy of Sciences. p. 35-69.

Hershkovitz, P. - 1972. The recent mammals of the neotropical region: a zoogeographic and ecological review. In: Keast, A.; Erk, F.C.; Glass, B. eds. Evolution, Mammals and Southern Continents. Albany, State University of New York. p. 311-431.

- 1977. Living New World Monkeys (Platyrrhini) vith an Introduction to Primates. Chicago, University of Chicago Press. v. 1, $1117 \mathrm{p}$. 
---- - 1979. The Species of Sakis, genus Pithecia (Cebidae, Primates) with notes on sexual dichromatism. Folia Primatol., 31: 1-22.

Izawa, K. - 1975. Foods and Feeding Behavior of Monkeys in the Upper Amazon Basin. Primates, 16: 295-316.

Izawa, K. \& Yoneda, M. - 1981. Habitat Utilization of Nonhuman Primates in a Forest of Western Pando, Vol. IV. Report of New World Monkeys. p. 13-22.

Mittermeier, R.A. \& Coimbra-Filho, A.F. - 1977. Primate Conservation in Brazilian Arazonia. In: Prince Rainier of Monaco \& Bourne, G. eds. - Primate Conservation. New York, Academic Press. 5:117-166.

Mitcermeier, R. A. \& van Roosmalen, M. G. M. - 1981. Preliminary Observations on Habitat Utilization and Diet in Eight Surinam Monkeys. Folia Primatol., 36: 1-39.

Moynihan, M. - 1976. The New World Primates. Princeton, N. J., Princeton University Press. $263 \mathrm{p}$.

Muckenhirr, N. A.; Mortensen, B. K.; Vessey, S.; Fraser, C. E. O.; Singh, B. - 1975. Report on a primate survey in Guyana, July-october. Report tc the Pan American Health Organization.

Napier, P. H. - 1976. Catalogue of Primates in the British Museum (Natural History) Part I: Families Cal1itrichidae and Cebidae.British Museum of Natural History. I21 p.

Neville, M. K. - 1976. Census of primates in Peru. In: Primate Censuring Studies in Peru and Colombia. Report to the National Acadeny of Science on Project AMRO - 0719 Pan American Heaith Organization.

Thornthwaite, C.W. - 1948. An approach toward a rational classification of climate. Geog. Rev., 38: 55-94.

van Roosmalen, M. G. M.; Mittermeier, R. A.; Milton, K. - 1981. The Bearded Sakis, Genus Chiropotes. In: Coimbra-Filho, A. F. \& Mittermeier, R. A. eds. Ecology and Behavior of Neotropical primates. Rio de Janeiro, Academia Brasileira de Ciencias,p.419-441.

(Aceito para publicação en 29.01.84) 